Katarzyna Konczewska

Polska Akademia Nauk w Krakowie

Instytut Języka Polskiego

ORCID: 0000-0002-3605-9974; e-mail: katarzyna.konczewska@ijp.pan.pl

\title{
Dialektologiczne badania terenowe na podstawie kolekcji muzealnej jako metoda budowania nowych kontekstów kulturowych
}

\begin{abstract}
Abstrakt: Dialektologiczne badania terenowe w areałach charakteryzujących się skomplikowaną sytuacją socjolingwistyczną wymagają od eksploratora wiedzy także historycznej i etnograficznej. W artykule została przedstawiona metoda badań kontaktów językowych na pograniczu w oparciu o materiały archiwalne i obiekty muzealne. Korzystając z tej metody, badacz otrzymuje możliwość odczytania nowych kontekstów kulturowych, pozyskania nowego materiału gwarowego, a nawet łatwiejszego nawiązania kontaktu z informatorami. Metoda ta pozwala także spojrzeć na muzealia jako pomocne instrumentarium w dialektologicznych badaniach terenowych, a nie wyłącznie „martwą” materię.
\end{abstract}

Słowa kluczowe: dialektologia, badania terenowe, muzealia, kontakty językowe na pograniczu.

\begin{abstract}
Dialectological field research based on a museum collection as a method of providing a new cultural contexts. Dialectological field research in areas with a complicated sociolinguistic situation requires the explorer to have historical and ethnographic knowledge. This paper presents a method of examining language contacts in a borderland based on archival materials and museum objects. By using this method, a researcher learns about new cultural contexts, obtains new dialect material; it also facilitates contacts with the informants. This method allows us to look at museum materials as helpful instruments in dialectological field research rather than only "dead" matter.
\end{abstract}

Keywords: dialectology, field research, museum materials, language contacts in a borderland.

\section{Wprowadzenie}

Przedmiotem moich badań są kontakty językowe na pograniczu słowiańsko-bałtyckim. W latach 2015-2019 prowadziłam systematyczne eksploracje terenowe ${ }^{1} \mathrm{w}$ wąskim areale po obydwóch stronach granicy polsko-białoruskiej ${ }^{2}$, na terenie wchodzącym

${ }^{1}$ Rozpoczęłam je w ramach samodzielnych badań (Konczewska 2021a). W 2016 r. zrealizowałam ich część w ramach programu stypendialnego dla zagranicznych naukowców Ministra Kultury i Dziedzictwa Narodowego Thesaurus Poloniae. W latach 2017-2019 prowadziłam je we współpracy z Muzeum Etnograficznym im. Seweryna Udzieli w Krakowie (MEK) w ramach projektu „Grodzieńszczyzna - symbol wielokulturowych Kresów. Badania i edukacja w oparciu o zbiory MEK oraz współpracę terenową”.

2 Pomiędzy miejscowościami: Geniusze i Odelsk po stronie białoruskiej oraz Krynki i Minkowce po stronie polskiej. 
przed ostatecznym ustanowieniem granicy państwowej w 1946 r. w skład jednej parafii usnarskiej $^{3}$ i jednego okręgu ${ }^{4}$ powiatu grodzieńskiego. Te pojaćwieskie niegdyś tereny o złożonym przebiegu osadnictwa nadal pozostają lakuną badawczą, a część miejscowości nie jest uwzględniona w znanych polskich i białoruskich atlasach gwarowych oraz opracowaniach leksykograficznych.

Skupiłam swoją uwagę na tym wąskim areale z kilku powodów. Po pierwsze praktycznie nie prowadzono w nim dotąd badań, być może ze względu na trudną dostępność spowodowaną lokalizacją miejscowości w ścisłej strefie przygranicznej. Po drugie z powodu bliskości granicy zamieszkują ten obszar przeważnie autochtoni, co zwiększa wiarygodność pozyskiwanego materiału gwarowego. Po trzecie jest tu usytuowane jedno z trzech zachowanych do naszych dni skupisk okolic (zaścianków) szlachty grodzieńskiej. Obecnie mieszczą się one po różnych stronach granicy, co predestynuje do badań porównawczych. Ponadto uważam, że eksploracje mikroregionów są niezwykle ważne w badaniach nad sytuacją socjolingwistyczną i kontaktami językowymi na terenach pogranicznych, bowiem pomagają sporządzić dokładny opis wszystkich lokalnych odrębności i ustalić zasięg zjawisk językowych. Na potrzeby badań opracowałam własną metodę eksploracji terenowych w oparciu o materiały archiwalne i obiekty muzealne postrzegane jako obraz przemian społeczno-kulturowych. W ten sposób obiekty muzealne uzyskują tożsamość, materiały archiwalne pomagają odtworzyć historyczną sytuację socjolingwistyczną, a badacz otrzymuje możliwość odczytania nowych kontekstów.

Dlaczego uznałam za potrzebne poszukiwanie nowej metody? Owszem, na temat prowadzenia badań nad wielojęzycznością i kontaktami językowymi na pograniczach zostało powiedziane już wiele; literatura przedmiotu jest bogata (Thomason 2001). Zagadnienia związane z założeniami metodologicznymi zarówno „tradycyjnej” dialektologii, jak i nowoczesnej socjolingwistyki rozwinął Janusz Rieger (2019, 99-110). Interesujące spostrzeżenia o metodologii badań na terenach pogranicznych przedstawił Björn Wiemer (2003, 212-229). Swoje uwagi o formule eksploracji terenowych na pograniczach Białorusi zaproponowały Elżbieta Smułkowa i Anna Engelking (2007, 15-18). Anna Zielińska zastosowała ciekawą metodę w badaniach na ziemi lubuskiej, terenie o skomplikowanej sytuacji socjolingwistycznej (Zielińska 2013). Jednak każdy badacz terenowy wie, że najlepsze metody eksploracji to takie, które dają efekty w określonym miejscu i czasie, czyli tu i teraz. Martyn Hammersley i Paul Atkinson zwracali uwagę, że katalog zasad i udanych przepisów na dobre badania terenowe nie istnieje, są jedynie dyskusje na temat głównych założeń metodologicznych (Hammersley, Atkinson 2000).

Badania na pograniczu wymagają od eksploratora opanowania aparatu pojęciowego w zakresie nie tylko dialektologii, ale także lingwistyki diachronicznej, porównawczej, arealnej, kulturowej oraz socjo- i etnolingwistyki. Należy jednak wziąć pod uwagę, że uniwersalne pojęcia wypracowane na przestrzeni kilkudziesięciu lat na podstawie

\footnotetext{
3 Po ustanowieniu granicy parafię, której centrum pozostało po stronie białoruskiej, przemianowano na makarowiecką, od nazwy wsi Makarowce (dawniej - Usnarz-Makarowce), gdzie znajduje się kościół parafialny.
}

${ }^{4} \mathrm{~W}$ okresie przynależności tych ziem do imperium rosyjskiego był to okręg numer 2 . 
obserwacji kontaktów różnych języków świata nie zawsze znajdują zastosowanie w złożonym świecie pogranicza.

\section{Specyfika terenu eksploracji}

Krzysztof Zajas trafnie zauważył o pograniczu, że jest to „nasz specyficzny, środkowoeuropejski wynalazek, który zawdzięcza swoją popularność wieloznaczności samego terminu «pogranicze», niosącego konotacje nie tylko przestrzenne, ale także kulturowe, polityczno-społeczne, językoznawcze, a nawet egzystencjalne" (Zajas 2012, 7-8). Pogranicze uparcie opiera się konceptualizacji. Andrzej Sadowski zwrócił uwagę, że na pograniczu polsko-białoruskim ,[...] podziały kulturowe nie mają charakteru dwudzielnego. Stanowią wzajemnie powiązaną całość wielokulturową, złożoną z podziałów religijnych, narodowych, językowych, regionalnych, lokalnych, których nie można sprowadzić do jakiegokolwiek jednego kryterium” (Sadowski 1997, 127).

Biorąc pod uwagę powikłane dzieje osadnictwa i skomplikowaną sytuację historyczno-polityczną w badanym areale, wydaje się, że w odniesieniu do niego bardziej precyzyjne jest określenie nie border (pogranicze), lecz transfrontalier (coś, co granicę przekracza). Tereny, leżące obecnie po obydwóch stronach granicy polsko-białoruskiej, przez stulecia tworzyły całość i pełniły funkcję tygla politycznego i narodowościowo-wyznaniowego. Na przestrzeni lat wchodziły one w skład różnych państw: ruskiego Księstwa Grodzieńskiego (XII - pierwsza połowa XIV); województwa trockiego Wielkiego Księstwa Litewskiego, a następnie Rzeczypospolitej Obojga Narodów (XIV-XVIII); guberni słonimskiej, litewskiej, grodzieńskiej imperium rosyjskiego (XVIII - początek XX); województwa białostockiego II Rzeczypospolitej (dwudziestolecie międzywojenne), a następnie Białoruskiej Sowieckiej Socjalistycznej Republiki Związku Radzieckiego (1939-1941); w czasie drugiej wojny światowej - okręgu białostockiego (Bezirk Bialystok) Rzeszy Niemieckiej. W 1946 r. jednolity terytorialnie od ponad 500 lat obszar został podzielony granicą i obecnie należy do Polski i Białorusi. Te ciągle zmieniające się państwowości wymownie przedstawił nieżyjący już pisarz Sokrat Janowicz, którego małą ojczyzną było miasteczko Krynki:

W 1936 roku powiększyłem liczbę obywateli Rzeczypospolitej Polskiej. Po trzech latach moją dużą ojczyzną stał się ZSSR, a po kolejnych dwóch latach znalazłem się w Nowych Prusach Wschodnich, czyli w III Rzeszy Niemieckiej, anektującej te ziemie. Ciągle biegając po tych samych zaułkach swego miasteczka lub kąpiąc się w pobliskiej rzeczułce Krynka, nigdzie nie ruszając się poza wzniesienie Prafitka na skraju horyzontu, odbyłem jak gdyby parę podróży zagranicznych... Różne ojczyzny pochłaniały moją jedyną małą (Janowicz 1993, 62).

Bardzo ważnym dla zrozumienia sytuacji tego subregionu jest fakt, iż jego tożsamość wykształciła się pod wpływem styku trzech religii monoteistycznych: chrześcijaństwa, judaizmu aszkenazyjskiego i islamu. Ponadto podział na chrześcijaństwo wschodnie (prawosławie) i zachodnie (katolicyzm, protestantyzm) przebiegał wzdłuż 
całego regionu. Specyficznym był też przebieg osadnictwa. Najpierw tereny te zamieszkiwały plemiona Bałtów, później dotarło tutaj osadnictwo Słowian. Jan Feliks Jakubowski, charakteryzując terytorium powiatu grodzieńskiego w XVI w., określał skład etniczny jego środkowej części jako mieszany litewsko-białoruski, jednak z przewagą liczebną elementu białoruskiego (Jakubowski 1935, 102). Zwracał też uwagę na osady drobnej szlachty o nazwiskach ruskich i litewskich ${ }^{5}$. Ustawa na wołoki z $1557 \mathrm{r}$. potwierdziła prawo do zamieszkiwania tych pogranicznych terenów przez bojarów putnych, pamięć o których jest zachowana w licznych toponimach i antroponimach subregionu. Już w XIV w., jako następstwo pierwszych unii polsko-litewskich, rozpoczął się napływ na te ziemie drobnej szlachty mazowieckiej i budników, wzmożony po unii lubelskiej 1569 r. Dodać należy, że ten areał zamieszkiwali także Tatarzy, którym darowali tu ziemię Witold (XIV w., nad rzeką Łosośną niedaleko Grodna, była to najliczniejsza wówczas wspólnota tatarska w Wielkim Księstwie Litewskim; obecnie Białoruś) i Jan III Sobieski (przełom XIV i XV w. wieś Kruszyniany, obecnie Polska). Ponadto z XIV w. w tej części Wielkiego Księstwa Litewskiego zaczęli osiedlać się Żydzi. Na terenie badanego areału najwięcej ich było w miasteczkach Indura, Krynki i Odelsk; pod Odelskiem do 1941 r. mieściła się Kolonia Isaaka, której mieszkańcy trudnili się rolnictwem.

Już w XVII w. subregion uformował się jako wielonarodowościowy (Litwini, Rusini, Polacy, Tatarzy, Żydzi), wielowyznaniowy (chrześcijaństwo, islam, judaizm) i wielostanowy (bojarzy, szlachta, chłopi). Tatarzy dość szybko zasymilowali się z miejscową ludnością . Skutkiem rozbiorów Rzeczypospolitej i wejścia jej wschodnich terenów w skład imperium rosyjskiego była masowa, przymusowa depolonizacja i rusyfikacja. W trakcie drugiej wojny światowej zagładzie uległa ludność żydowską. Po wojnie na terenach, które znalazły się ponownie w Związku Radzieckim, prowadzono nagminną rusyfikację, a znaczna część miejscowych Polaków wyjechała w ramach dwóch fal tak zwanej repatriacji do Polski. Z kolei na terenach, które weszły w skład Polski, mieszkańcy pochodzenia białoruskiego byli polonizowani i przez długi okres czasu nie przyznawali się do białoruskości i wyznania prawosławnego. Tuż po wojnie miało też miejsce przymusowe, rzadziej dobrowolne ich przesiedlenie na tereny sowieckie.

Ważnym składnikiem tożsamości w badanym areale był język ${ }^{7}$. Stąd twarda samoidentyfikacja: język polski - szlachta, Polacy, mówienie „po prostu” - chłopi, „tutejsi”. Ciągłe zmiany przynależności państwowej tych terenów przejawiały się nie tylko w postaci kolejnego dokumentu tożsamości z wpisanymi na nowo imieniem i nazwiskiem, lecz także w języku, wyznaniu, światopoglądzie mieszkańców. W miejscowościach przygranicznych, tak jak w opisywanych przez Janowicza Krynkach, prawie każdy był poliglotą:

5 Od strony antroponimicznej zbadała je Julia Górska (Гурская 2012,142-150; 2014,182-206).

${ }^{6} \mathrm{~W}$ ostatnich latach aktywnie się odradza wspólnota tatarska w Kruszynianach.

7 Analiza wyników spisu ludności na wschodnich terenach, przeprowadzona przez Eugeniusza Romera (1920), wykazała, że wyznanie i narodowość nie zawsze się pokrywają, mylna więc jest identyfikacja katolik $=$ Polak i prawosławny $=$ Białorusin. 
Białoruszczyzna uchodziła za normalną w codziennym bytowaniu, rosyjski nadawał się do cerkwi i konwersacji z Panem Bogiem, polski znakomicie dowartościowywał jednostkę w jej chętkach wywyższenia się ponad pospólstwo, po niemiecku pisano podania do różnych „amtów” lub listy do mężów i ojców w niewoli gdzieś w Saksonii albo w Prusach; ukraiński pasował do anegdot. Niemal pięciojęzycze indukowało schizofreniczne rozszczepienie jaźni, a w praktyce kończyło się tym, że w miarę przyzwoicie nie potrafiono posługiwać się żadnym z wymienionych języków (Janowicz 1993, 64).

Obecnie badany obszar zamieszkują katolicy i prawosławni, przeważnie Polacy i Białorusini, będący potomkami drobnej szlachty lub chłopów, a wspomniane przez S. Janowicza czterojęzycze (wyłączywszy niemiecki) pozostało do naszych dni. Po rosyjsku modlą się w cerkwi prawosławni po obydwóch stronach granicy, a po polsku - katolicy w kościele. Po stronie białoruskiej język polski poza sferą sacrum jest językiem domowym mieszkańców dawnych okolic szlacheckich. Gwarą białoruską posługują się mieszkańcy dawnych wsi chłopskich po stronie zarówno białoruskiej, jak i polskiej, przy tym wyraźnie odróżniając mówienie ,po białorusku” od mówienia ,po prostu”. Ten drugi idiolekt oznacza dla nich język, którym posługują się na co dzień, w kontaktach domowych i sąsiedzkich; ta „prosta mowa” może mieć podstawę zarówno białoruską, jak polską, w zależności od aspektów socjolingwistycznych. Elementy ukraińskie można dostrzec w języku osób prawosławnych.

\section{Metodologia w praktyce}

Badania prowadzę na poziomie makro- (ujęzykowienie pamięci o historycznej i obecnej wspólnocie komunikatywnej, jej świadomości językowej i tożsamościowej) i mikrojęzykowym (materiał gwarowy), z uwzględnieniem aspektu socjolingwistycznego, kulturoznawczego i antropologicznego. Specyfika moich badań polega nie tylko na eksploracji areału transgranicznego jako całości, lecz także na nietradycyjnym założeniu metodologicznym polegającym na badaniu całokształtu kontaktów językowych. Takie podejście, z uwzględnieniem czynników ekstralingwistycznych, w tym wyznaniowego i socjalnego, przynosi nową wiedzę o rzeczywistości językowej i zdecydowanie rozszerza dotychczasowe badania nad gwarami tego pogranicza praktykowane zazwyczaj w zakresie jednego języka, co dawało efekt poznawczy ograniczony do rozpoznania tylko jednego aspektu wielojęzyczności. W swoich badaniach próbuję wyjść poza modele badawcze tradycyjnego językoznawstwa, uwzględniając także dorobek etnografów i etnohistoryków. Wykorzystuję różne narzędzia opisu, stosuję podejście diachroniczne i analizę porównawczą, konfrontując perspektywy badawcze polską i białoruską w celu obiektywnego spojrzenia na problematykę. Prowadzone w ten sposób badania są istotne zarówno dla komparatystycznych rozważań slawistycznych, jak i rozwoju dialektologii, a także dla antropolingwistycznych studiów nad pograniczem. Przynoszą nową wiedzę w zakresie wciąż niewystarczająco zbadanych kontaktów bałto-słowiańskich, stanu polszczyzny północno-wschodniej oraz rozwoju gwar pogranicza. Poza tym wprowadzanie ich wyników do polskiej i białoruskiej przestrzeni kulturowej pozwala na stworzenie płaszczyzny do lepszego zrozumienia się i docenienia wspólnego dziedzictwa. 
Przedstawiona wyżej w znacznym skrócie specyficzna sytuacja socjolingwistyczna badanego areału wymaga równie specyficznego podejścia. Założyłam, że najlepiej będzie zacząc od materiałów archiwalnych, które pomogą odtworzyć jego historyczną sytuację socjolingwistyczną. Przeprowadziłam kwerendę w Państwowym Archiwum Historycznym Białorusi w Grodnie, gdzie są przechowywane księgi parafialne z tego subregionu, a także różnorodne niezwykle szczegółowe sprawozdania statystyczne sporządzone przez carskich urzędników. Wynikiem tej kwerendy było ustalenie historii osadnictwa, sytuacji stanowej każdej z miejscowości, sporządzenie list zamieszkujących je rodów, prześledzenie zmian socjolingwistycznych zachodzących w ciągu stuleci. W 2018 r. otrzymałam drugie stypendium badawcze Thesaurus Poloniae, dzięki któremu mogłam przeprowadzić dokładną kwerendę w archiwum i inwentarzach MEK. Wychodziłam z założenia, że skoro było to jedno z pierwszych polskich muzeów etnograficznych, a w czasie jego powołania poszukiwania etnograficzne prowadzono na szeroką skalę i były one wręcz modne wśród inteligencji nawet w najmniejszych miejscowościach, uda mi się znaleźć coś wartego uwagi o badanym terenie, mimo że jest dość odległy od Krakowa. I rzeczywiście tak się stało. Kwerenda wykazała, że na początku XX w. muzeum prowadziło szeroką działalność badawczą, a liczni darczyńcy przesyłali tu swoje materiały ze wszystkich zakątków Polski, w tym z okolic Grodna ${ }^{8}$. Wówczas pojawiło się pytanie, w jaki sposób materiały kwerendy mogą służyć obecnie prowadzonym badaniom, co należy uczynić, by je wykorzystać, traktując jako materiały pomocnicze, a nie wyłącznie „martwe” eksponaty. Powstał pomysł, by poszerzyć wiedzę o wyekscerpowanej przeze mnie kolekcji, którą umownie nazwałam „,białoruską”, na drodze badań terenowych, a nie tylko przy pracy ze źródłami. Zależało nam, wspólnie z Magdaleną Zych, opiekującą się ze strony MEK projektem „Grodzieńszczyzna - symbol wielokulturowych Kresów. Badania i edukacja w oparciu o zbiory MEK oraz współpracę terenową", na zbudowaniu wokół wybranych obiektów kontekstów kulturowych.

Punktem wyjścia była przeprowadzona kwerenda oraz praca z archiwaliami i muzealiami MEK, którą podejmowałam w latach 2017-2018 poza okresami badań terenowych. Zadaniem rozpoznania w terenie było ustalenie funkcji poszczególnych elementów wybranych obiektów oraz odpowiedź na pytanie, co dzisiaj mogą powiedzieć obiekty muzealne o mieszkańcach tych terenów i co mówią im samym. Chodziło o spojrzenie na obiekty muzealne jak na obraz przemian społeczno-kulturowych, nieuniknionych w tak specyficznej sytuacji jak ustalenie granicy państwowej skutkujące podzieleniem terenów wspólnych niegdyś kulturowo i językowo. W ten sposób obiekty muzealne uzyskują tożsamość, a badacz ma możliwość odczytania nowych kontekstów kulturowych.

Na podstawie materiałów kolekcji muzealnej przeprowadziłam dwie ekspedycje terenowe w latach 2018 i 2019, dalsze badania zahamowała pandemia. Przedmiotem ekspedycji z 2018 r. było tkactwo i obróbka lnu', a ekspedycji z 2019 r. - budownic-

\footnotetext{
${ }^{8}$ Wynikiem kwerendy jest przygotowanie opracowania o kolekcji MEK z białoruskich terenów dawnej Rzeczypospolitej.

9 Wyniki przedstawiłam w artykule Regionalne słownictwo gwarowe dotyczace obróbki lnu i tkactwa na terenie dawnej parafii usnarskiej na Grodzieńszczyźnie (Konczewska 2020, 175-189).
} 
two $^{10}$. Pierwszą ekspedycję przeprowadziłam w areale po obydwóch stronach granicy, a punktem jej wyjścia były obiekty muzealne. Drugą zrealizowałam tylko po stronie polskiej, na podstawie niepublikowanych materiałów rękopiśmiennych zdeponowanych w archiwum MEK będących pokłosiem wyprawy badającej budownictwo, organizowanej przez Romana Reinfussa w 1967 r., jedynej jak dotychczas na tych terenach.

Podczas eksploracji przeprowadzonej w 2018 r. w trakcie wywiadów prezentowałam informatorom poszczególne zdjęcia wyekscerpowanych muzealiów pochodzących z tych terenów i prosiłam o swobodną wypowiedź na ich temat. Zostały rozpoznane prawie wszystkie z dwudziestu wybranych obiektów, z wyjątkiem dwóch prastarych, jednak nie każdy informator rozpoznał wszystkie. Z wypowiedzi informatorów można wnioskować, że część obiektów była używana wyłącznie przez mieszkańców dawnych wsi chłopskich i była nieznana w okolicach szlacheckich. Wśród przedstawionych do zidentyfikowania obiektów były liczne próbki samodziału wełnianego, kolorowego, a także następujące wyroby samodziałowe: koszula pastusza z grubego szarego płótna (nr inw. 2082) ${ }^{11}$, kurtka pastusza $\mathrm{z}$ grubego włochatego samodziału brunatnego (nr inw. 2084), spódnica samodziałowa wełniana, uszyta z 4 brytów (nr inw. 66326), spódnica uszyta z 3 brytów tkaniny, samodziałowa (nr inw. 66440), świtka kobieca uszyta z grubego szarego sukna, długa, wcięta w stanie (nr inw. 8259), zapaska z białego płótna (nr inw. 8258), pas wełniany domowego wyrobu (nr inw. 2085).

Ekspedycja ta poza nagraniami miejscowych gwar polskich i białoruskich zaowocowała bogatym materiałem leksykalnym z następujących pól semantycznych: uprawa lnu, wstępna obróbka lnu, przygotowanie włókna do tkania, tkactwo, materiał i wyroby samodziałowe. Ponadto zebrałam materiał faktograficzny pomocny w zrekonstruowaniu procesu tkactwa na dzisiejszym pograniczu polsko-białoruskim. Wyniki badań potwierdziły wyraźną różnicę w języku, obyczajach, prowadzeniu gospodarki i tradycyjnych rzemiosłach, w tym tkactwie, w dawnych okolicach szlacheckich i wsiach chłopskich. Jako przykład przytoczę różne określenia tych samych desygnatów pozyskane w okolicy szlacheckiej i wsi chłopskiej: kijanka/pranik 'drewniana łopatka służąca do prania bielizny i obijania lnu', międlić/tarkować 'poddawać słomę lnianą lub konopną łamaniu i zgniataniu w celu oddzielenia paździerzy od włókien’, pakuły/pakule/kłocza 'krótkie, splątane włókna lnu lub konopi', szczotka/szczutka/czesałka 'narzędzie składające się z oprawki z umocowanym w niej pionowo drutem, służące do wyczesywania lnu', terlica/c'ernica 'drewniany przyrząd używany dawniej do międlenia lnu i konopi', bierdo/berdko/bierda 'grzebień tkacki, część warsztatu tkackiego do przybijania wątku', trzepak/trepaczka 'narzędzie do wytrzepywania paździerzy z włókien lnu', warsztat/krosna 'warsztat tkacki', dygun/dzygun 'dywan tkany jednym kolorem'.

Ekspedycję 2019 r. dotyczącą budownictwa przeprowadziłam na podstawie archiwaliów z zasobów Instytutu Sztuki Polskiej Akademii Nauk zdeponowanych w MEK ${ }^{12}$. Materiały z badań terenowych zrealizowanych w 1967 r. pod kierunkiem Romana Re-

\footnotetext{
10 Jej materiały zaprezentowałam na konferencji „Język w regionie - region w języku 4” w 2020 r. (Konczewska 2021b).

${ }^{11}$ Opisy inwentarzowe muzealiów są podane w skrócie.

${ }^{12} \mathrm{I} / 1235$, sygn. II/936.
} 
infussa zasługują na uwagę $\mathrm{z}$ dwóch powodów. Po pierwsze były to jedne $\mathrm{z}$ nielicznych prowadzonych na wschodnich terenach Polski, w wąskim pasie przy granicy polsko-białoruskiej, w miejscowościach pomiędzy Supraślem a Krynkami. Po drugie niektóre $\mathrm{z}$ notatek zawierają ciekawy materiał nie tylko z dziedziny budownictwa, ale także z zakresu życia dawnej wsi, stosunków wyznaniowych i stanowych, obrzędów dorocznych i tradycji, pracy na roli. Planowe badania terenowe nad całokształtem sztuki ludowej tak dawnej, jak i współczesnej na terenie całej Polski, w tym jej najdalszych wschodnich terenów, zapoczątkowano w latach powojennych. Przeważnie kilkuosobowe zespoły docierały do najbardziej odległych zakątków kraju. Efektem tych eksploracji były zarówno rysunki oraz zdjęcia, jak i niezwykle ciekawe rękopiśmienne sprawozdawania i wywiady. Materiały gromadzone w latach 50.-60. oraz 70.-90. XX w. dotyczące obszarów wschodnich nie są liczne, jednak dotąd nie zostały należycie opracowane, a w związku z tym stanowią cenne źródło wiedzy. Szczególnie ciekawe są notatki z dawnego powiatu białostockiego i sokólskiego sporządzone przez Jerzego Czajkowskiego i Bogumiłę Dziki. Raporty i spisane wywiady z autochtonami autorstwa tych badaczy szczegółowo przedstawiają miejscowe zwyczaje, obrzędy, ówczesną sytuację na wsi, a także w niektórych przypadkach lokalne słownictwo gwarowe, co dało możliwość do przeprowadzenia badań porównawczych. Zainteresowały mnie przede wszystkim materiały autorstwa profesora Czajkowskiego, który jako jedyny z eksploratorów nie tylko szczegółowo precyzował informacje o badanej miejscowości (wieś białoruska, wieś polska czy osada szlachecka), ale także sporządzał na kwestionariuszu eksploracyjnym słowniczek dotyczący słownictwa $\mathrm{z}$ zakresu budownictwa. Pod koniec 2019 r., 4 listopada pojechałam do Sanoka, gdzie spotkałam się z badaczem $^{13}$ i przeprowadziłam wywiad $\mathrm{w}$ celu uzyskania informacji o przebiegu eksploracji w latach 60. XX w., wykorzystanej wówczas metodologii i przyczynie wyboru terytorium, co dało mi rozeznanie w kwestii sposobu materiałów. Efekty badań zespołu stały się podstawą mojej ekspedycji, w trakcie której odwiedziłam te same miejscowości, konfrontując wyekscerpowany materiał z wypowiedziami moich informatorów. Do badań także wybrałam różne typy osad: wieś prawosławna, katolicka i okolica szlachecka. W ten sposób mogłam zweryfikować materiał i sprawdzić obecną znajomość leksemów zarejestrowanych w latach 60 . XX w., co pozwoliło na wysunięcie wniosków o zachowaniu bądź modyfikacji gwary i prześledzenie jej rozwoju. Zauważę, że część tego materiału nie jest poświadczona $\mathrm{w}$ znanych źródłach leksykograficznych i atlasach, czyli w trakcie tak prowadzonych badań mamy możliwość pozyskania nowego materiału gwarowego. Wywiady przeprowadziłam z sześcioma informatorami w różnym wieku, w tym dwoma ze wsi prawosławnej, dwoma ze wsi katolickiej i dwoma z okolicy szlacheckiej. W każdej grupie dobierałam przedstawicieli różnych pokoleń w celu zweryfikowania znajomości leksemów u każdego z nich. Wyniki eksploracji wykazały, że leksyka w zakresie budownictwa, tak jak uprawy lnu i tkactwa, różni się w języku potomków szlachty i chłopów, np.: wystawalakap 'okap poszerzony nad frontem budynku', cioska/brusy 'bale w ścianie', czapka/dymnik 'kapa nad kuchnią', podwalina/podruba 'fundament', spichrz/stodoła 'osobny budynek na zboże', pogrze-

13 Profesor J. Czajkowski od stycznia 1972 r. do kwietnia 1999 r. pełnił funkcję dyrektora Muzeum Budownictwa Ludowego w Sanoku; obecnie, będąc na emeryturze, mieszka na jego terenie. 
bacz/kluczka 'pręt stalowy używany do wygarniania węgli z paleniska'. Niektóre leksemy mają inną postać w dawnych okolicach szlacheckich, wsiach katolickich i wsiach prawosławnych: pułap/potap/hara 'miejsce pod strzechą', bale/brusy/bruse 'gruby, budulcowy pień drzewa'. Pozyskany materiał poświadcza w języku mieszkańców wsi prawosławnych cechy białoruskiej gwary grodzieńskiej: bruse (akcentowana końcówka - $e$ w mianowniku liczby mnogiej rzeczowników rodzaju męskiego, których temat kończy się na spółgłoskę twardą), padworko (akanie niepełne, rozróżnienie samogłosek $o$ i $a$ w końcowej sylabie otwartej po spółgłoskach twardych). Zarejestrowano także leksemy niepoświadczone w znanych źródłach leksykograficznych, np. leżajka 'część pieca chlebowego służąca do spania ${ }^{14}$.

\section{Podsumowanie}

Dialektologiczne badania terenowe $\mathrm{w}$ areałach charakteryzujących się skomplikowaną sytuacją socjolingwistyczną wymagają od eksploratora wiedzy nie tylko językoznawczej i socjologicznej, ale także historycznej i etnograficznej. Pomocne w przygotowaniu i prowadzeniu takich eksploracji mogą być materiały archiwalne i muzealne pochodzące z penetrowanych obszarów. W trakcie badań terenowych obiekty muzealne uzyskują tożsamość, a także mogą się przyczynić do pozyskiwania nowego materiału gwarowego i historii mówionej, stając się punktem wyjścia ciekawych wywiadów. Materiały archiwalne pomagają odtworzyć historyczną sytuację socjolingwistyczną, co jest niezbędne do zrozumienia jej aktualnego stanu, a także mogą być źródłem do badań wielojęzyczności historycznej oraz wyekscerpowania materiału leksykalnego stanowiącego podstawę weryfikacji w trakcie ekspedycji dialektologicznej. Korzystając z tej metody, badacz otrzymuje możliwość odczytania nowych kontekstów kulturowych, pozyskania nowego materiału gwarowego, a nawet łatwiejszego nawiązania kontaktu $\mathrm{z}$ informatorami, ponieważ ma do zaoferowania cząstkę ich historii. Prowadzone $\mathrm{w}$ ten sposób badania pomagają także uniknąć błędów wynikających z nieznajomości przez eksploratora specyfiki konkretnej miejscowości lub dawnego bytu wiejskiego, ponieważ opierają się na udokumentowanej bazie materiałowej. Przedstawiona metoda badań pozwala również spojrzeć na kolekcję muzealną jako na pomocne instrumentarium w dialektologicznych badaniach terenowych, a nie wyłącznie „martwą” materię.

\section{Literatura}

Hammersley M., Atkinson P. (2000), Metody badań terenowych, Poznań.

Jakubowski J.F. (1935), Powiat grodzieński w w. XVI (mapa z tekstem), „Prace Komisji Atlasu Historycznego Polski", z. III, Kraków, s. 99-114.

Janowicz S. (1993), Terra incognita: Białoruś, Białystok.

${ }^{14}$ To ją właśnie miała na myśli Leonia Kowalska, matka głównego bohatera filmu Sami swoi, narzekając na kuchenkę w poniemieckim domu: „Upiec upieczesz, ale spać gdzie?”. 
Konczewska K. (2020), Regionalne słownictwo gwarowe dotyczace obróbki lnu i tkactwa na terenie dawnej parafii usnarskiej na Grodzieńszczyźnie, [w:] Język w regionie, region w języku, t. 3, red. B. Osowski, J. Kobus, P. Michalska-Górecka, A. Piotrowska-Wojaczyk, Poznań, s. 175-189.

Konczewska K. (2021a), Polacy i język polski na Grodzieńszczyźnie, Kraków.

Konczewska K. (2021b), Podlaskie stownictwo gwarowe z zakresu budownictwa (na podstawie niepublikowanych materiałów archiwalnych Instytutu Sztuki Polskiej Akademii Nauk $i$ wspótczesnych badań terenowych (w druku).

Rieger J. (2019), Język polski na Kresach, Warszawa.

Romer E. (1920), Prace geograficzne, z. VII: Spis ludności na terenach administrowanych przez zarząd cywilny ziem wschodnich (grudzień 1919) z mapa, Lwów.

Sadowski A. (1997), Identyfikacja narodowa na pograniczu polsko-białoruskim, „Studia Etnologiczne i Antropologiczne", t. 1, s. 115-127.

Smułkowa E., Engelking A. (2007), Uwagi o metodzie badań terenowych na pograniczach Białorusi, [w]: Pogranicza Białorusi w perspektywie interdyscyplinarnej, red. E. Smułkowa, A. Engelking, Warszawa, s. 15-18.

Thomason S. (2001), Language contact, Edinburgh.

Wiemer B. (2003), Zur Verbindung dialektologischer, soziolinguistischer und typologischer Methoden in der Sprachkontaktforschung (am Beispiel slavischer und litauischer Varietäten in Nordostpolen, Litauen und Wießrußland), „Zeitschrift für Slawistik”, Bd. 48 (2), s. 212-229.

Zajas K. (2012), Widnokręgi literatury, [w:] Na pograniczach literatury, red. J. Fazan, K. Zajas, Kraków, s. 7-8.

Zielińska A. (2013), Mowa pogranicza. Studium o językach i tożsamościach w regionie lubuskim, Warszawa.

Гурская Ю. [Gurskaia Yu.] (2012), Древние фамилии в онимических системах славянских и балтийских языков [Drevnie familii $v$ onimicheskikh sistemakh slavianskikh i baltiǔskikh iazykov] „Respectus Philologicus”, т. 21 (26), c. 142-150.

Гурская Ю. [Gurskaia Yu.] (2014), Деантропонимные топонимы белорусско-польского пограничья [Deantroponimnye toponimy belorussko-polskogo pogranichia], „Acta Baltico-Slavica”, т. 38 , c. 182-206. 